\title{
Effects of peroxisome proliferator-activated receptor activation on gonadotropin transcription and cell mitosis induced by bone morphogenetic proteins in mouse gonadotrope $L \beta T 2$ cells
}

\author{
Masaya Takeda, Fumio Otsuka, Hiroyuki Otani, Kenichi Inagaki, Tomoko Miyoshi, Jiro Suzuki, \\ Yukari Mimura, Toshio Ogura and Hirofumi Makino \\ Department of Medicine and Clinical Science, Okayama University Graduate School of Medicine, Dentistry and Pharmaceutical Sciences, 2-5-1 Shikata-cho, \\ Okayama City 700-8558, Japan \\ (Requests for offprints should be addressed to F Otsuka; Email: fumiotsu@md.okayama-u.ac.jp)
}

\begin{abstract}
Involvement of peroxisome proliferator-activated receptor- $\gamma$ $(\mathrm{PPAR}-\gamma)$ activation and bone morphogenetic protein (BMP) signaling in regulating cell proliferation and hormonal production of pituitary tumors has been reported, although the underlying mechanism remains poorly understood. Here, we investigated regulatory roles of PPAR $\alpha$ and PPAR $\gamma$ in gonadotropin transcription and cell mitosis modulated by pituitary activin/BMP systems using a mouse gonadotropinoma cell line $\mathrm{L} \beta \mathrm{T} 2$, which expresses activin/BMP receptors, transcription factor Smads, PPAR $\alpha$, and PPAR $\gamma$. In L $\beta$ T2 cells, BMP signaling shown by Smad1/5/8 phosphorylation and Id-1 transcription was readily activated by BMPs. A PPAR $\gamma$ agonist, pioglitazone significantly reduced BMPinduced DNA synthesis by L $\beta T 2$; whereas the PPAR $\alpha$ agonist, fenofibric acid, did not. In accordance with the effects on cell mitosis, pioglitazone but not fenofibric acid significantly decreased BMP-induced Id-1-Luc activation.
\end{abstract}

Neither fenofibric acid nor pioglitazone affected activin signaling detected by (CAGA) $)^{9}$-Luc activity. Both PPAR $\alpha$ and $\operatorname{PPAR} \gamma$ ligands directly suppressed transcriptional activities of FSH $\beta$, LH $\beta$, and GnRHR. Activation of PPAR $\alpha$ and PPAR $\gamma$ increased mRNA levels of follistatin, but did not affect the expression of follistatin-related gene. Thus, PPAR agonists not only directly suppress gonadotropin transcription and BMP signaling, but also inhibit the biological actions of activins which facilitate gonadotropin transcription through upregulating follistatin expression. In addition, pioglitazone increased BMP ligands mRNA, but decreased activin- $\beta B$ mRNA in L $\beta$ T2 cells. Collectively, PPAR activation differentially regulates gonadotrope cell proliferation and gonadotropin transcription in a liganddependent manner.

Journal of Endocrinology (2007) 194, 87-99

\section{Introduction}

Peroxisome proliferator-activated receptors (PPARs) that include PPAR $\alpha, \operatorname{PPAR} \beta / \delta$, and PPAR $\gamma$ belong to the family of nuclear hormone receptors, which are related to thyroid hormone, retinoic acid, androgen, and estrogen receptors (Desvergne \& Wahli 1999). PPAR $\gamma$ is activated after the binding of natural ligands such as polyunsaturated fatty acids and prostaglandin metabolites (Willson et al. 2000). $\operatorname{PPAR} \gamma$ is also activated by synthetic ligands thiazolidinediones, e.g. rosiglitazone, pioglitazone, or troglitazone (Lehmann et al. 1995). The binding of thiazolidinediones to their receptors increases insulin sensitivity, and most bind primarily to PPAR $\gamma$ in adipose cells. PPAR $\gamma$ is expressed abundantly in adipose tissue, colon, and hemopoietic cells, moderately in kidney, liver and small intestine, and in small amounts in skeletal muscle (Gurnell 2005). PPAR $\gamma$ was originally described as having a primary role in adipocyte differentiation, but more recent studies have implicated it in processes of inflammation, atherosclerosis, cell cycle control, apoptosis, and carcinogenesis (Auwerx 1999). PPARs act as a transcription factor when heterodimerized with the retinoid $\mathrm{X}$ receptor and bound to the proper ligands, including natural and synthetic ligands.

Recent studies have revealed that PPAR $\gamma$ is expressed in pituitary adenomas and PPAR $\gamma$ ligands suppress proliferation and hormonal production of pituitary tumors. Heaney et al. (2002) first demonstrated that PPAR $\gamma$ expression is restricted to adrenocorticotropin (ACTH)-secreting cells of the normal human anterior pituitary. Moreover, PPAR $\gamma$ is also expressed in human ACTH-secreting pituitary tumors causing Cushing's disease and the activation of PPAR $\gamma$ potently inhibits cell proliferation as well as ACTH secretion of the pituitary adenomas (Heaney et al. 2002). These results support the role for PPAR $\gamma$ as a novel target for treating patients with Cushing's disease. They further reported that pituitary PPAR $\gamma$ is abundantly expressed in human prolactin-, growth hormone-producing, and nonfunctioning 
pituitary tumors, and that PPAR $\gamma$ agonists potently inhibit tumor growth and hormonal secretion of these pituitary adenomas (Heaney et al. 2003). These results indicated a possible role for PPAR $\gamma$ as a novel molecular target for treating patients with various pituitary tumors that are unresponsive to current dopamine agonists and/or somatostatin receptor antagonists. However, the underlying mechanism has yet to be elucidated.

Bone morphogenetic proteins (BMPs) belong to the transforming growth factor- $\beta$ (TGF- $\beta$ ) superfamily. BMPs were originally identified as the active components in bone extracts capable of inducing bone formation at ectopic sites. A variety of physiological BMP actions in many endocrine tissues, including the ovary (Otsuka et al. 2000, 2001, Miyoshi et al. 2007), pituitary (Otsuka \& Shimasaki 2002, Takeda et al. 2003), thyroid (Suzuki et al. 2005), and adrenal (Suzuki et al. 2004, Kano et al. 2005, Inagaki et al. 2006), have been recently clarified. We previously reported the characteristics regarding human follicle-stimulating hormone (FSH)-producing adenomas compared with nonfunctioning adenomas, in which the levels of follistatin mRNA were decreased in FSH-producing adenomas (Takeda et al. 2003). There is increasing evidence that locally produced BMPs, which can also be functionally regulated by follistatin, play critical roles in differentiation of pituitary gonadotrope. For instance, BMP-4 promotes pituitary prolactinoma pathogenesis through a Smad-estrogen receptor crosstalk (Paez-Pereda et al. 2003), whereas BMP-4 inhibits corticotropic pathogenesis and Cushing's disease in adult pituitary tumor cells (Giacomini et al. 2006). Thus, the pituitary BMP system seems likely to act as a regulator not only for organogenesis and differentiation process of pituitary cells, but also for transformation and tumorigenesis of the differentiated pituitary cells.

In the present study, we investigated the mechanism by which PPAR agonists regulate transcription of gonadotropins using L $\beta$ T2 cell line derived from mouse gonadotrope tumors that express activin/BMP ligands, type I and type II BMP receptors and Smad signaling molecules. Here, we uncovered that PPAR activation plays a differential role in controlling gonadotropin transcription and tumorigenesis of pituitary gonadotrope cells by regulating an endogenous $\mathrm{BMP} /$ activin system.

\section{Materials and Methods}

\section{Reagents and supplies}

Dulbecco's modified Eagle's medium (DMEM), penicillinstreptomycin solution, and dimethylsulfoxide (DMSO) were purchased from Sigma-Aldrich Co. Ltd. Recombinant human BMP-2, BMP-4, BMP-6 and BMP-7, and activin A were purchased from R\&D Systems Inc. (Minneapolis, MN, USA). Pioglitazone and fenofibric acid were provided from Takeda Chemical Industries
(Osaka, Japan) and Kaken Pharmaceutical Co. Ltd (Tokyo, Japan) respectively. L $\beta \mathrm{T} 2$ cells were provided by Dr Pamela L Mellon, University of California San Diego. Plasmids of Id-1-Luc were provided from Dr Tetsuro Watabe and Dr Kohei Miyazono, Tokyo University, Japan. Plasmids of oFSH $\beta$-Luc which contains $4741 \mathrm{bp}$ of ovine FSH $\beta$ promoter, luteinizing hormone $\beta$ (LH $\beta)$-Luc which contains $1800 \mathrm{bp}$ of rat LH $\beta$ promoter, and gonadotropinreleasing hormone receptor (GnRHR)-Luc which contains $1227 \mathrm{bp}$ of mouse GnRHR promoter were gifted by Dr Pamela L Mellon and Dr William L Miller, North Carolina State University.

\section{Cell culture and thymidine incorporation assay}

L $\beta$ T2 cells were grown in DMEM containing 10\% fetal calf serum (FCS) supplemented with penicillin-streptomycin at $37^{\circ} \mathrm{C}$ in an atmosphere of $5 \% \mathrm{CO}_{2}$ in air. Cells were grown in $10 \mathrm{~cm}$ dishes until they became confluent and were transferred into 12 -well plates at a concentration of $3 \times 10^{4}$ viable cells/well. After preculture, medium was replaced with fresh DMEM containing 1\% FCS and indicated combinations of BMPs and PPAR ligands were added to the culture medium. After $24-\mathrm{h}$ culture, $0 \cdot 5 \mu \mathrm{Ci} / \mathrm{ml}$ [methyl- ${ }^{3} \mathrm{H}$ ] thymidine (Amersham Pharmacia) was added, and incubated for $3 \mathrm{~h}$ at $37^{\circ} \mathrm{C}$. The incorporated thymidine was detected as we previously reported (Takeda et al. 2004). Cells were then washed with PBS, incubated with $10 \%$ ice-cold trichloroacetic acid for $60 \mathrm{~min}$ at $4{ }^{\circ} \mathrm{C}$, and solubilized in $0.5 \mathrm{M} \mathrm{NaOH}$, and radioactivity was determined with a liquid scintillation counter (TRI-CARB 2300TR, Packard Co., Meriden, CT, USA).

\section{Transient transfection and luciferase assay}

L $\beta$ T2 cells were grown in $10 \mathrm{~cm}$ plates until they became confluent and then replaced into 24 -well plates. After $24-\mathrm{h}$ preculture, the cells $(\sim 60 \%$ confluent $)$ were transiently transfected with $500 \mathrm{ng}$ of each luciferase reporter plasmid and $50 \mathrm{ng}$ cytomegalovirus- $\beta$-galactosidase plasmid (pCMV- $\beta$-gal) using FuGENE 6 transfection reagent (Roche Molecular Biochemicals) for $24 \mathrm{~h}$. Cells were treated with BMPs, activins, and PPAR ligands in fresh DMEM containing 1\% FCS for $24 \mathrm{~h}$ and the cells were washed with PBS and lysed with Cell Culture Lysis Reagent (Toyobo, Osaka, Japan). Luciferase activity and $\beta$-galactosidase ( $\beta$-gal) activity of the cell lysate were measured by luminescencerPSN (ATTO, Tokyo, Japan), as reported previously (Miyoshi et al. 2006). The data were shown as the ratio of luciferase to $\beta$-gal activity.

\section{RNA extraction, RT-PCR, and quantitative real-time PCR} analysis

To prepare total cellular RNA, L $\beta$ T2 cells were cultured in 12 -well plate $\left(5 \times 10^{5}\right.$ viable cells) and treated with 
indicated concentrations of growth factors and PPAR ligands in fresh DMEM containing 1\% FCS. After 24-h culture, the medium was removed, and total cellular RNA was extracted using TRIzol reagent (Invitrogen Corp.), quantified by measuring absorbance at $260 \mathrm{~nm}$, and stored at $-80{ }^{\circ} \mathrm{C}$ until assay. Total RNAs of anterior pituitary, ovary, and kidney tissues were extracted from adult male Wistar rats and $\mathrm{BALB} \mathrm{c}$ mice using TRIzol reagent. The expression of BMP receptors, binding proteins, and Smad mRNAs were detected by RT-PCR analysis. The extracted RNA $(1 \cdot 0 \mu \mathrm{g})$ was subjected to an RT reaction using the First-Strand cDNA synthesis system (Invitrogen Corp.) with random hexamer $(2 \mathrm{ng} / \mu \mathrm{l})$, reverse transcriptase $(200 \mathrm{U})$, and deoxy-NTP $(0.5 \mathrm{mM})$ at $42{ }^{\circ} \mathrm{C}$ for $50 \mathrm{~min}$ and $70{ }^{\circ} \mathrm{C}$ for $10 \mathrm{~min}$. Subsequently, hot-start PCR was performed using $\mathrm{MgCl}_{2}(1.5 \mathrm{mM})$, deoxy-NTP $0.2 \mathrm{mM}$ ), and $2.5 \mathrm{U}$ Taq DNA polymerase (Invitrogen Corp.) under the same condition. Oligonucleotides used for RT-PCR were custom-ordered from Kurabo Biomedical Co. (Osaka, Japan). PCR primer pairs were selected from different exons of the corresponding genes as follows: activin receptor-like kinase-2 (ALK-2), 639-661 and 1100-1121 (from GenBank accession no. NM_007394); ALK-3, 426-445 and 916-935 (from NM_009758); ALK-4, 130-150 and 637-657 (from NM_007395); ALK-6, 598-617 and 1034-1053 (from NM_007560); activin type II receptor (ActRII), 611-630 and 1083-1102 (from NM_007396); ActRIIB, 130-154 and 377-400 (NM_007397); BMP type II receptor (BMPRII), 13-32 and 515-534 (from NM_007561); Smad1, 878-899 and 1193-1214 (from NM_008539); Smad2, 111-131 and 535-555 (from NM_010754); Smad3, 474-494 and 828848 (from NM_016769); Smad4, 712-732 and 1082-1102 (from NM_008540); Smad5, 636-658 and 1062-1083 (from NM_008541); Smad6, 1081-1101 and 1527-1547 (from NM_008542); Smad7, 1912-1932 and 2328-2348 (from AJ000550); Smad8, 271-291 and 538-558 (from AF175408); follistatin, 361-385 and 525-550 (from NM_008046); follistatin-related gene (FLRG), 632-651 and 910-929 (from AF276238); PPAR $\alpha, 601-622$ and 932-953 (from NM_011144); PPAR $\gamma, 350-371$ and 721-742 (from NM_011146); and a housekeeping gene, ribosomal protein L19 (RPL19), 373-393 and 547-567 (from NM_009078). Aliquots of PCR products were electrophoresed on 1.5\% agarose gels and visualized after ethidium bromide staining. For the quantification of follistatin and FLRG mRNA levels, real-time PCR was performed using LightCycler-FastStart DNA Master SYBR Green I system (Roche Diagnostic Co.) under conditions of annealing at $60{ }^{\circ} \mathrm{C}$ with $4 \mathrm{mM} \mathrm{MgCl}_{2}$, following manufacturer's protocol. Accumulated levels of fluorescence were analyzed by the second derivative method after the melting curve analysis (Roche Diagnostic), and then the expression levels of target genes were standardized by RPL19 level in each sample.

\section{Western immunoblot analysis}

Cells $\left(2 \times 10^{5}\right.$ viable cells) were precultured in 12 -well plates in DMEM containing 10\% FCS for $24 \mathrm{~h}$. After preculture, medium was replaced with serum-free fresh DMEM, and then indicated concentrations of BMPs and PPAR ligands were added to the culture medium. After stimulation with growth factors for $1 \mathrm{~h}$, cells were solubilized in $100 \mu \mathrm{l}$ RPA lysis buffer (Upstate Biotechnology, Inc., Lake Placid, NY, USA) containing $1 \mathrm{mM} \mathrm{Na}_{3} \mathrm{VO}_{4}, 1 \mathrm{mM}$ sodium fluoride, $2 \%$ sodium dodecyl sulfate, and $4 \% \beta$-mercaptoethanol. The cell lysates were then subjected to SDS-PAGE/immunoblotting analysis using anti-phospho-Smad1/5/8 antibody (Cell Signaling Technology Inc., Beverly, MA, USA).

\section{Immunofluorescence microscopy}

Cells were precultured in serum-free DMEM and then cells at $\sim 50 \%$ confluency were treated with BMPs. After 1-h stimulation, cells were fixed with $4 \%$ formaldehyde in PBS, permeabilized with $0.5 \%$ Triton X-100 in PBS at room temperature, and washed thrice with PBS. The cells were then incubated with anti-phospho-Smad1/5/8 antibody for $1 \mathrm{~h}$ and washed thrice with PBS. Cells were then incubated with Alexa Flour 488 anti-rabbit IgG (Invitrogen Corp.) in a humidified
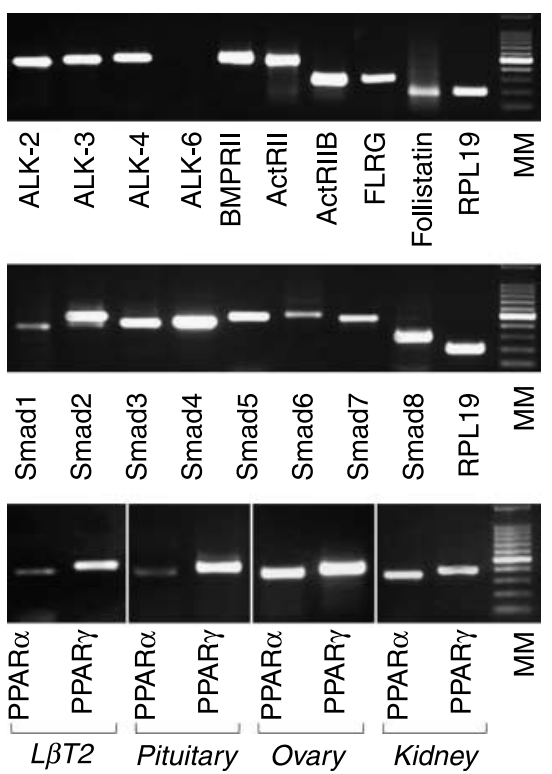

Figure 1 Expression of BMP system and peroxisome proliferatoractivated receptors (PPARs) in $L \beta T 2$ cells. The expression of mRNAs encoding BMP type I and II receptors, binding proteins, Smads, and a housekeeping gene RPL19 was examined by RT-PCR in total cellular RNA extracted from L $\beta$ T2 cells. Expression pattern of PPAR $\alpha$ and PPAR $\gamma$ mRNA from L $\beta$ T2 cells was compared with that from rat anterior pituitary, mouse ovary, and mouse kidney tissues by RT-PCR. Aliquots of PCR products were electrophoresed on $1 \cdot 5 \%$ agarose gel, visualized by ethidium bromide staining and shown as representative of those obtained from three independent experiments. MM indicates molecular weight marker. 

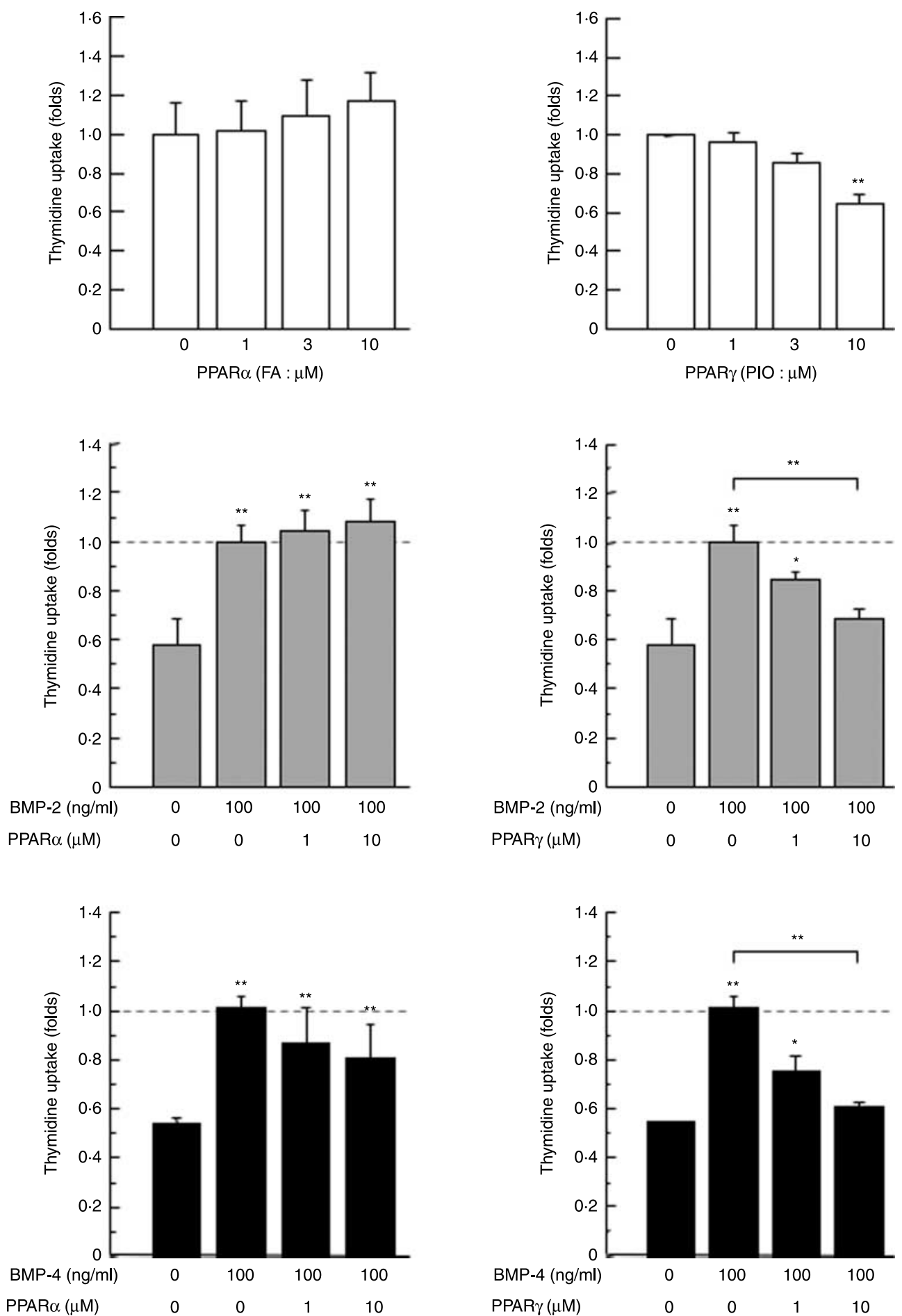

Figure 2 Effects of PPAR activation on DNA synthesis by L $\beta T 2$ cells. After preculture, cells $\left(3 \times 10^{4}\right.$ viable cells) were treated with indicated concentrations of fenofibric acid (FA, a PPAR $\alpha$ agonist), pioglitazone (PIO, a PPAR $\gamma$ agonist), and BMP-2 and BMP-4. After 24-h culture, $0.5 \mu \mathrm{Ci} /$ well of [methyl- ${ }^{3} \mathrm{H}$ ] thymidine was added and incubated for $3 \mathrm{~h}$ at $37^{\circ} \mathrm{C}$. Cells were then washed, precipitated by trichloroacetic acid and solubilized in $\mathrm{NaOH}$ and its radioactivity was counted. Results show the mean \pm s.E.M. of data performed with triplicate incubations. ${ }^{*} P<0 \cdot 05$ and ${ }^{* *} P<0 \cdot 01$ versus control or between the indicated groups. 

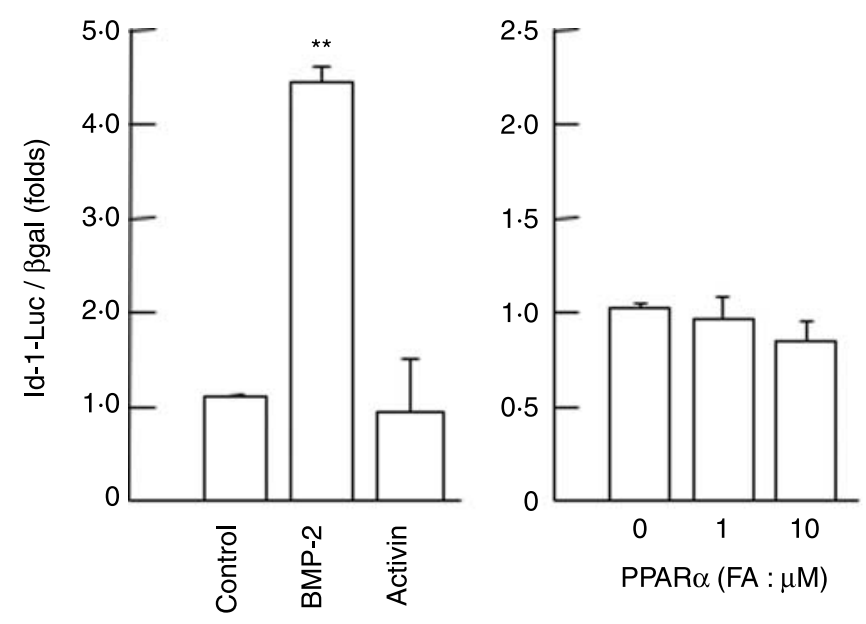
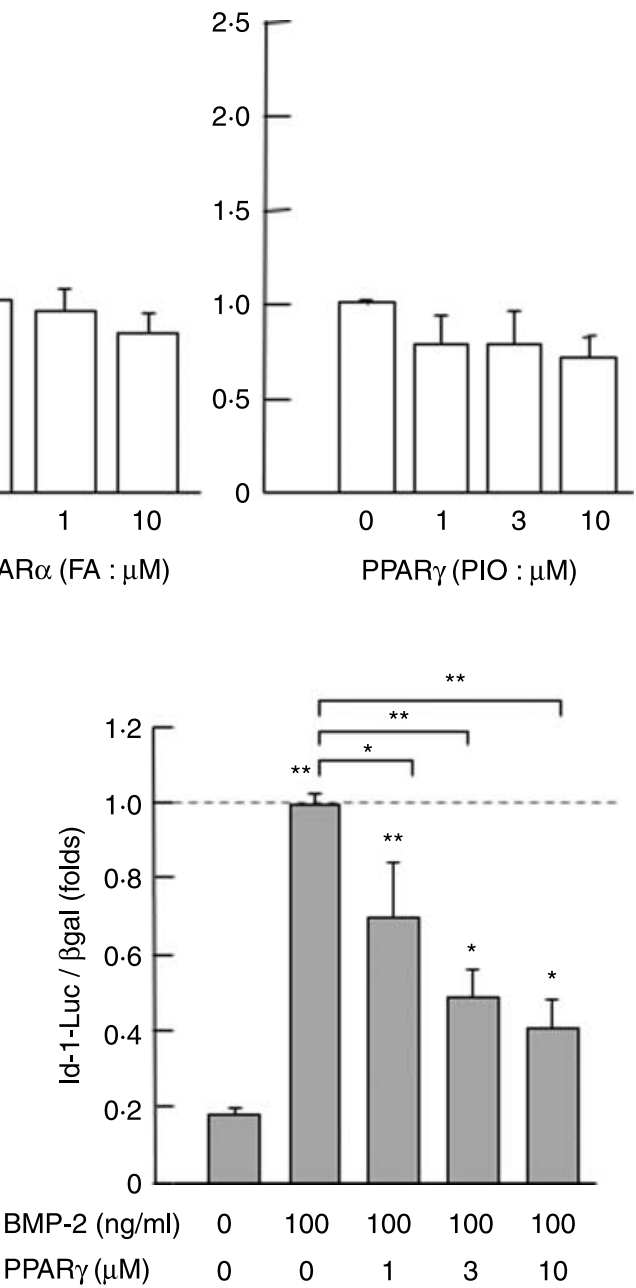

Figure 3 Effects of PPAR activation on BMP signaling in L $\beta$ T2 cells. After preculture, cells were transiently transfected with $500 \mathrm{ng}$ Id-1-Luc and $50 \mathrm{ng}$ cytomegalovirus- $\beta$-galactosidase plasmid (pCMV- $\beta$-gal). Cells were then treated with indicated concentrations of PPAR agonists (PPAR $\alpha$, FA: fenofibric acid; PPAR $\gamma$, PIO: pioglitazone) and BMP-2/activin A (100 ng/ml) for $24 \mathrm{~h}$. Cells were washed with PBS, lysed, and the luciferase and $\beta$-galactosidase ( $\beta$ gal) activities were measured by luminometer. Results were shown as the ratio of luciferase to $\beta$ gal activity and graphed as mean \pm S.E.M. of data performed with triplicate treatments. ${ }^{*} P<0 \cdot 05$ and ${ }^{* *} P<0 \cdot 01$ versus control or between the indicated groups.

chamber for $1 \mathrm{~h}$ and washed with PBS, and then stained cells were visualized under a fluorescent microscope.

\section{cDNA array analysis}

GEArray system (SuperArray Bioscience Corp., Frederick, MD, USA) that includes 96 genes of mouse TGF- $\beta$ and BMP signaling pathway was used for analyzing the expression pattern of BMP signaling system in L $\beta \mathrm{T} 2$ cells. As reported previously (Miyoshi et al. 2006), extracted total RNAs $(3.0 \mu \mathrm{g})$ were used as templates to generate biotin-16-dUTP-labeled cDNA probes according to manufacturer's instruction. The cDNA probes were denatured and hybridized at $60^{\circ} \mathrm{C}$ with the cDNA array membranes, which were washed and exposed to X-ray films with use of chemiluminescent substrates. To analyze the array results, we scanned the X-ray film and the image was inverted as grayscale TIFF files. The spots were digitized and analyzed using GEArray analyzer software (SuperArray Bioscience Corp.) and the data were normalized by subtraction of the background as the average intensity levels of three spots containing plasmid DNA of pUC18. The averages of two spots of glyceraldehyde-3phosphate dehydrogenase and four spots of cyclophilin A (PPIA) were used as positive controls to compare the membranes. Using these standardized data, we compared the signal intensity of the membranes using the GEArray analyzer program (SuperArray Bioscience Corp.). 


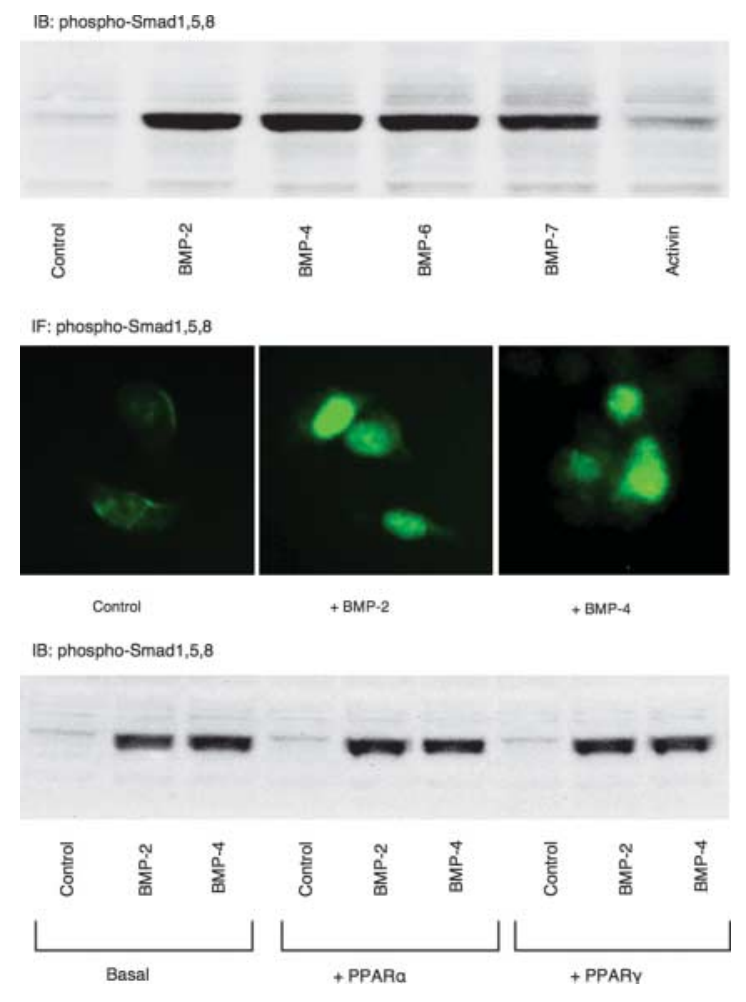

Figure 4 Effects of PPAR agonists on Smad1/5/8 phosphorylation in L $\beta$ T2 cells. After $24-\mathrm{h}$ preculture, cells $\left(2 \times 10^{5}\right.$ viable cells) were treated with BMP-2, BMP-4, BMP-6 and BMP-7, and activin A $(100 \mathrm{ng} / \mathrm{ml})$ in combination with PPAR agonists (PPAR $\alpha$, fenofibric acid; PPAR $\gamma$, pioglitazone; $10 \mu \mathrm{M}$ ) in serum-free conditions. Following 1-h stimulation with growth factors, cells lysates were obtained and then subjected to SDS-PAGE/immunoblotting (IB) analysis using anti-phospho-Smad1/5/8 antibody. Immunofluorescent (IF) studies were also performed using $\mathrm{pSmad} 1 / 5 / 8$ antibody on BMP-treated cells for $1 \mathrm{~h}$.

\section{Statistical analysis}

All results are shown as means \pm s.E.M. of data from at least three separate experiments, each performed with triplicate samples. Differences between groups were analyzed for statistical significance using ANOVA (StatView 5.0 software, Abacus Concepts Inc., Berkeley, CA, USA). $P<0 \cdot 05$ were accepted as statistically significant.

\section{Results}

We first examined the mRNA expression of components of the activin/BMP system by RT-PCR analysis in L $\beta T 2$ cells. The expression of BMP type I receptors, including ALK-2 (also called ActRIA), ALK-3 (BMPRIA), and ALK-4 (ActRIB); BMP type II receptors, including ActRII, ActRIIB, and BMPRII; binding proteins, including FLRG and follistatin; and Smad signaling molecules, including
Smad1/2/3/4/5/8; and inhibitory Smads, Smad6/7 were detected (Fig. 1). ALK-6 (BMPRIB) mRNA expression was not detected in L $\beta T 2$ cells. PPAR $\gamma$ mRNA expression was detected at comparatively higher levels than PPAR $\alpha$ in L $\beta$ T2 cells, which parallels the expression pattern of PPARs in normal anterior pituitary tissues in rat. In contrast, mouse ovary and kidney tissues expressed PPAR $\alpha$ and PPAR $\gamma$ mRNA at similar levels (Fig. 1).

As shown in Fig. 2, a PPAR $\gamma$ agonist, pioglitazone, but not the PPAR $\alpha$ agonist, fenofibric acid, suppressed cellular DNA synthesis shown by thymidine incorporation at a high dose of $10 \mu \mathrm{M}$. Cell mitosis induced by BMP-2 and BMP-4 was suppressed by pioglitazone, but not fenofibric acid (Fig. 2). To assess the mechanism by which PPAR ligands affect BMP signaling in L $\beta$ T2 cells, intracellular signaling activity of BMP was examined using BMP-Smad1/5/8 pathway-specific reporter, Id-1-Luc. As shown in Fig. 3, BMP-2, but not activin A, increased Id-1-Luc activity, while PPAR ligands had no specific effects on Id-1-Luc activity. BMP-2 induction of Id-1-luc was specifically reduced by the PPAR $\gamma$ agonist but not by the PPAR $\alpha$ agonist in a dose-dependent manner. Western blots analysis demonstrated rapid phosphorylation of Smad1/5/8 protein induced by BMP-2, BMP-4, BMP-6, and BMP-7 (Fig. 4). Immunofluorescence study clearly demonstrated nuclear localization of the phosphorylated Smad1/5/8 molecules by treatments with BMP-2 and BMP-4 (Fig. 4). Smad phosphorylation induced by BMP-2 and BMP-4 was not affected even in the presence of PPAR agonists (Fig. 4), suggesting that the PPAR activation inhibits BMP signal transduction at the downstream of Smad1/5/8 phosphorylation in L $\beta \mathrm{T} 2$ cells.

We next examined the transcriptional regulation of FSH $\beta$, LH $\beta$, and GnRHR in L $\beta$ T2 cells. As shown in Fig. 5, activin $A$, but not BMP-2, stimulated transcription of FSH $\beta$, LH $\beta$, and GnRHR. Importantly, in striking contrast with the established concept that activin does not stimulate LH $\beta$ mRNA expression or LH synthesis in primary pituitary cells, activin did stimulate LH $\beta$ transcription in L $\beta$ T2 cells. Similar data were previously reported by Pernasetti et al. (2001).

It was of note that PPAR agonists suppressed transcriptional activities of FSH $\beta, L H \beta$, and GnRHR in L $\beta$ T2 cells (Fig. 5). To assess the mechanism by which PPAR agonists affect activin signaling in L $\beta$ T2 cells, we used the activin-Smad2/3-specific reporter (CAGA) ${ }^{9}$-Luc. PPAR $\alpha$ and PPAR $\gamma$ agonists had no direct effects on (CAGA) ${ }^{9}$-Luc activity. In addition, neither $\operatorname{PPAR} \alpha$ nor $\operatorname{PPAR} \gamma$ agonists affected (CAGA) ${ }^{9}$-Luc activation induced by exogenously added activin A (Fig. 6). Therefore, it is likely that PPAR $\alpha$ and PPAR $\gamma$ directly inactivate transcription of FSH $\beta, L H \beta$, and GnRHR without affecting Smad2/3 signaling in L $\beta$ T2 cells.

Interestingly, follistatin expression was increased in a dose-dependent manner by PPAR agonists (Fig. 7). In contrast, expression of FLRG, another activin-binding 

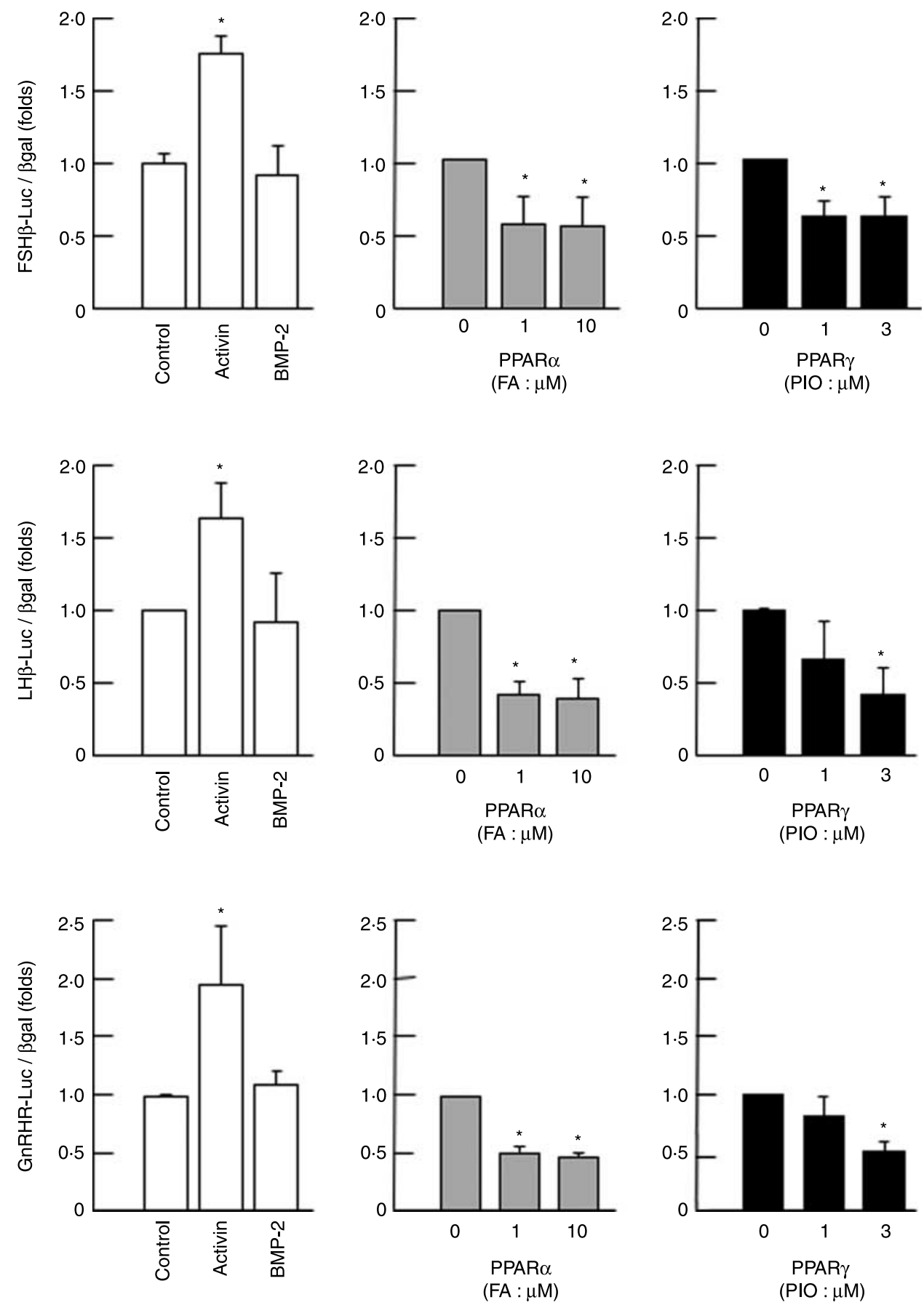

Figure 5 Effects of PPAR agonists on gonadotropin and GnRHR transcription by L $\beta T 2$ cells. Cells were precultured in 12-well plates and then transiently transfected with 500 ng FSH $\beta$-Luc, LH $\beta$-Luc and GnRHRLuc, and 50 ng cytomegalovirus- $\beta$-galactosidase plasmid (pCMV- $\beta$-gal). Cells were treated with indicated concentrations of PPAR agonists (PPAR $\alpha$, FA: fenofibric acid; PPAR $\gamma$, PIO: pioglitazone) and activin A/BMP-2 $(100 \mathrm{ng} / \mathrm{ml})$ for $24 \mathrm{~h}$. Cells were washed with PBS, lysed, and the luciferase and $\beta$-galactosidase ( $\beta$ gal) activities were measured by luminometer. Results were shown as the ratio of luciferase to $\beta$ gal activity and graphed as mean \pm S.E.M. of data performed with triplicate treatments. $* P<0 \cdot 05$ versus control. 

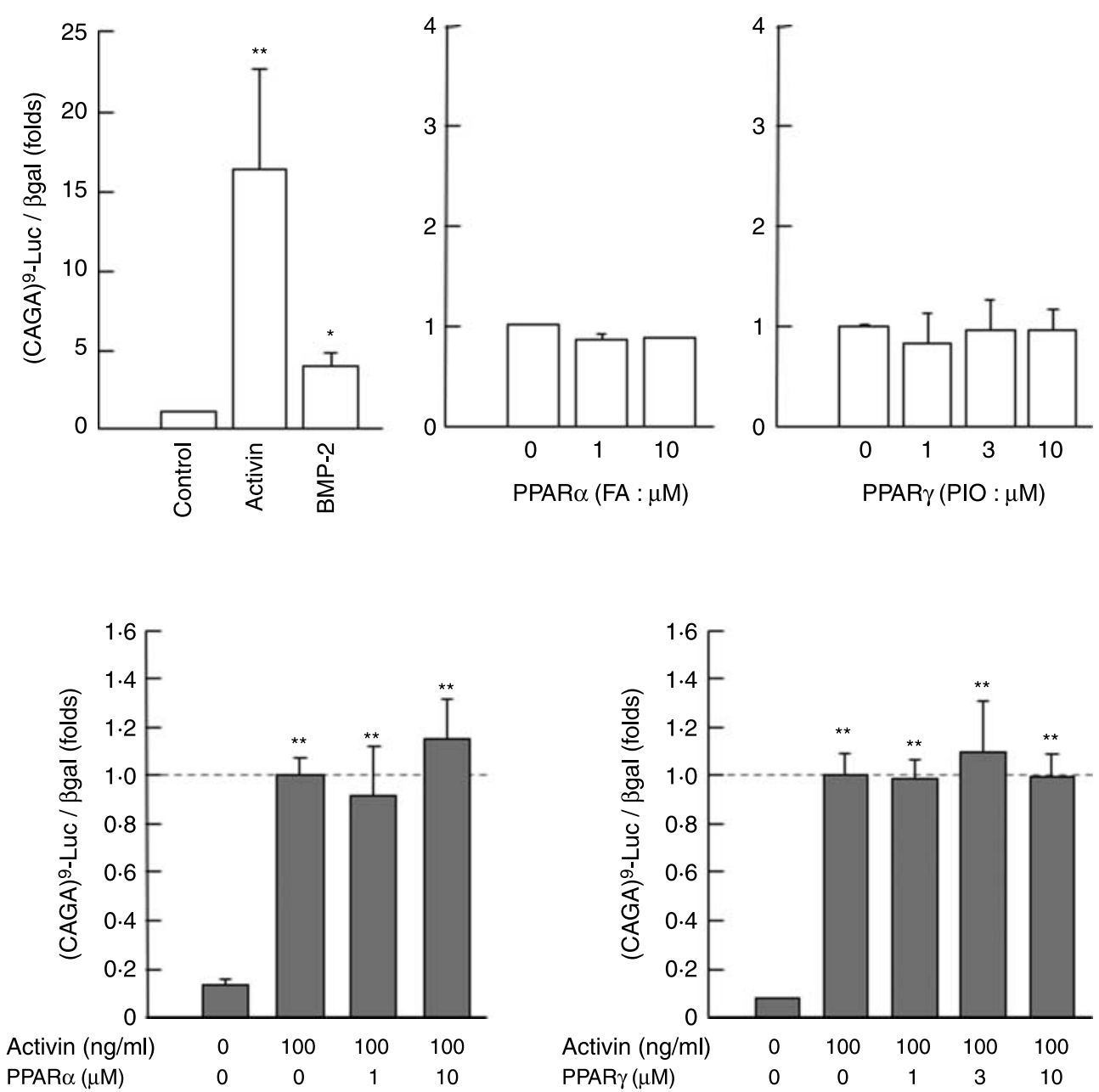

Figure 6 Effects of PPAR activation on activin signaling in L $\beta T 2$ cells. After preculture, cells were transiently transfected with $500 \mathrm{ng}(\mathrm{CAGA})^{9}$-Luc and 50 ng cytomegalovirus- $\beta$-galactosidase plasmid (pCMV- $\beta$-gal). Cells were then treated with indicated concentrations of PPAR agonists (PPAR $\alpha$, FA: fenofibric acid; PPAR $\gamma$, PIO: pioglitazone) and activin A/BMP-2 $(100 \mathrm{ng} / \mathrm{ml})$ for $24 \mathrm{~h}$. Cells were washed with PBS, lysed, and the luciferase and $\beta$-galactosidase ( $\beta$ gal) activities were measured by luminometer. Results were shown as the ratio of luciferase to $\beta$ gal activity and graphed as means \pm S.E.M. of data performed with triplicate treatments. ${ }^{*} P<0 \cdot 05$ and ${ }^{* *} P<0 \cdot 01$ versus control.

protein, was not altered by PPAR agonists. Activin A induced FLRG expression in L $\beta$ T2 cells (Fig. 7). Thus, PPAR agonists not only directly suppress gonadotropin transcription and BMP signaling, but also indirectly inhibit the biological actions of activins/BMPs through the upregulation of follistatin expression. BMP ligands, including BMP-2, BMP-4, BMP-6 and BMP-7, as well as the inhibin- $\alpha$ and activin- $\beta \mathrm{B}$ subunits are expressed in L $\beta \mathrm{T} 2$ cells (Otsuka \& Shimasaki 2002). In the present study, changes in the expression of BMP ligands were investigated by cDNA array analysis (Fig. 8). In the presence of PPAR $\gamma$ agonists, the expression of BMP ligands, including BMP-2, BMP-3, BMP-4, BMP-6, BMP-7, and BMP-8a, were increased, while that of activin- $\beta \mathrm{B}$ subunit was decreased in L $\beta$ T2 cells.

\section{Discussion}

In the present study, the effects of PPAR $\alpha$ and PPAR $\gamma$ activation on transcriptional regulation of gonadotropins were investigated in L $\beta \mathrm{T} 2$ cells, which express activin/BMP receptors, Smad2/3 and Smad1/5/8, and PPAR $\alpha$ and $\operatorname{PPAR} \gamma$. A PPAR $\gamma$ agonist, pioglitazone, but not a $\operatorname{PPAR} \alpha$ agonist, fenofibric acid, significantly reduced BMP-induced DNA synthesis by L $\beta T 2$. In accordance with the effects on cell mitosis, PPAR $\gamma$ but not PPAR $\alpha$ activation inhibited the BMP signaling evidenced by Id-1Luc activity (Fig. 9).

Heaney et al. (2003) demonstrated an interesting observation using L $\beta$ T2 cells subcutaneously injected into nude mice. Tumor weights increased and plasma LH levels 

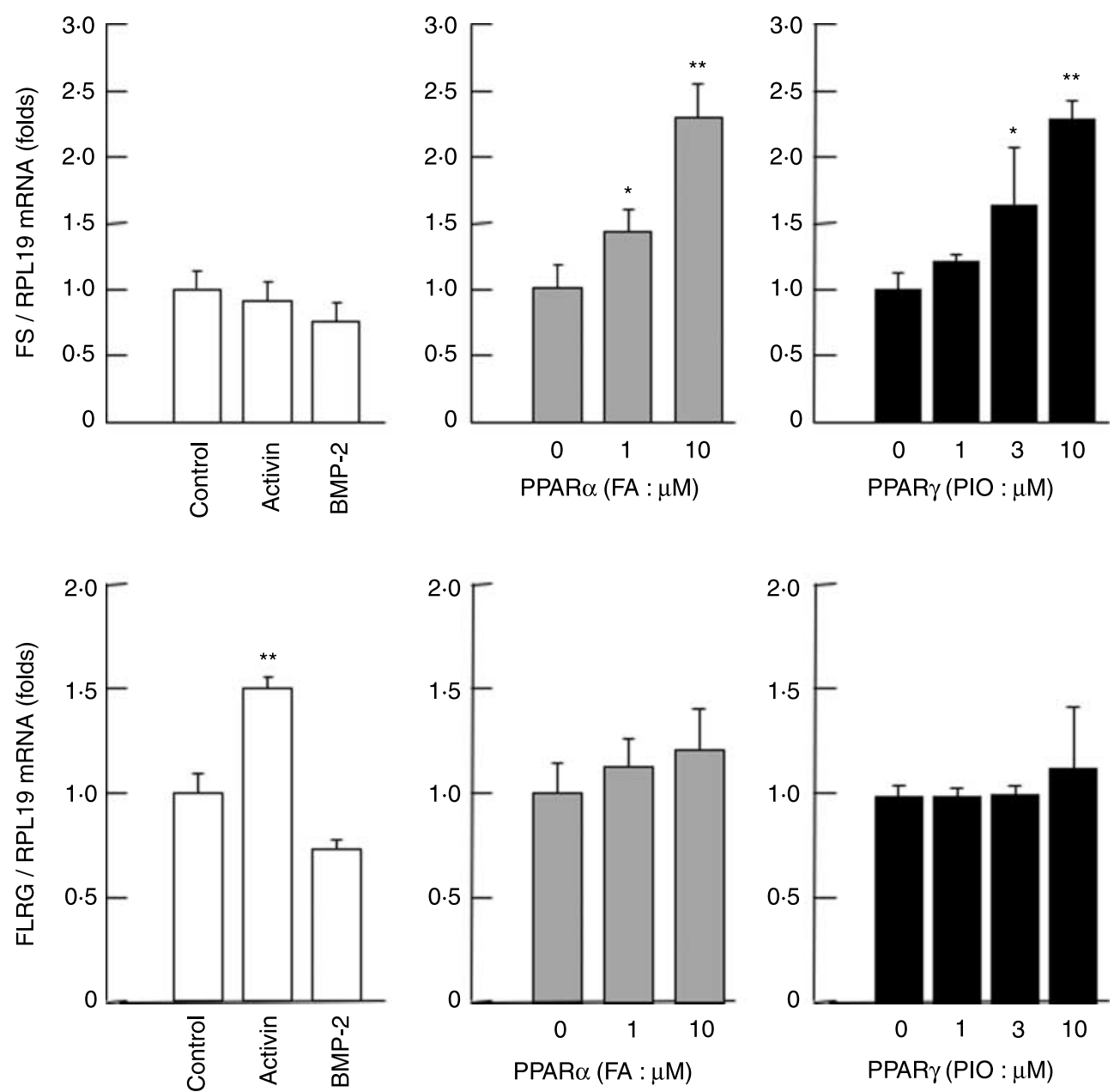

Figure 7 Effects of PPAR agonists on mRNA expression of follistatin (FS) and follistatin-related gene (FLRG) in L $\beta$ T2 cells. After preculture, cells $\left(4 \times 10^{5}\right.$ viable cells) were treated with indicated concentrations of PPAR agonists (PPAR $\alpha$, FA: fenofibric acid; PPAR $\gamma$, PIO: pioglitazone) and activin A/BMP-2 (100 ng/ml). Total cellular RNAs were extracted and subjected to RT reaction. Levels of steady-state mRNAs of FS and FLRG were analyzed by quantitative real-time PCR and standardized by level of RPL19 in each sample. Changes of the mRNA levels by treatments were graphed. Results show the mean \pm S.E.M. of data performed with triplicate treatments. ${ }^{*} P<0 \cdot 05$ and ${ }^{* *} P<0 \cdot 01$ versus control.

were markedly decreased in mice treated with high-dose $(>$ $20 \mathrm{mg} / \mathrm{kg}$ per day) of rosiglitazone, although low-dose $(5 \mathrm{mg} / \mathrm{kg}$ per day) rosiglitazone was insufficient for inhibiting the tumor growth. These results confirm the potent effects of PPAR $\gamma$ activation on anti-proliferation in vivo and demonstrate the potential role of PPAR $\gamma$ ligands for therapy in gonadotrope and nonfunctioning pituitary tumors (Heaney 2003).

PPAR $\gamma$ acts as a transcription factor, and its involvement in adipocyte differentiation led to studies on anti-proliferative effects of PPAR $\gamma$ activation on various neoplasms (Lefebvre et al. 1998). The anti-proliferative effects of PPAR $\gamma$ ligands are related to activation of cyclin-dependent kinase inhibitors (p21 and p27), reduction of cyclins D1 and E, and induction of apoptosis via activation of caspase 3 and inhibition of anti-apoptotic proteins $(\mathrm{Bcl}-2$ and $\mathrm{Bcl}-\mathrm{XL})$, although recent data suggest that the suppression of cell growth by rosiglitazone may be, at least in part, via a $\operatorname{PPAR} \gamma$ independent pathway (Palakurthi et al. 2001, Emery et al. 2006). In addition to the inhibitory effects of PPAR $\gamma$ agonist on BMP-induced L $\beta$ T2 cell mitosis, both PPAR $\alpha$ and PPAR $\gamma$ agonists directly reduced transcriptional activities of FSH $\beta$, LH $\beta$, and GnRHR. These ligands also increased mRNA levels of an activin-binding protein, follistatin. Thus, PPAR $\alpha$ and PPAR $\gamma$ activation differentially regulates gonadotrope cell proliferation and gonadotropin transcription in a ligand-dependent manner (Fig. 9).

Recent reports have suggested that BMPs are directly involved in regulating gonadotrope function. Huang et al. (2001) reported that BMP-6 and BMP-7 stimulate FSH 


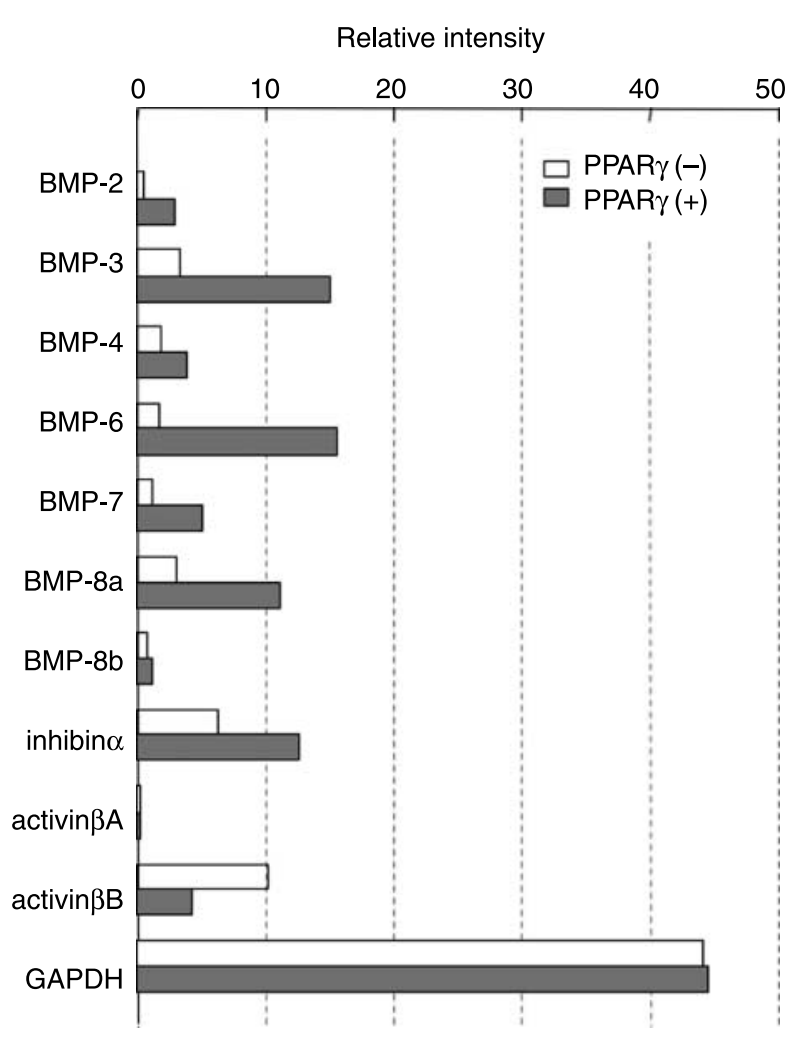

Figure 8 Effects of PPAR activation on the expression pattern of $\mathrm{BMP}$ ligands in L $\beta T 2$ cells. Total cellular RNAs ( $3 \mu \mathrm{g})$ were extracted from $L \beta T 2$ cells cultured for $24 \mathrm{~h}$ in the absence $(-)$ or presence $(+)$ of a PPAR $\gamma$ agonist, pioglitazone $(10 \mu \mathrm{M})$. The RNAs were used as templates to generate biotin-16-dUTP-labeled cDNA probes for GEArray membranes (SuperArray Bioscience Corp.) that include human TGF- $\beta$ and BMP signaling molecules. The CDNA probes were denatured and hybridized with the cDNA array membranes and then the membranes were washed and exposed to X-ray films using chemiluminescent substrate. The spots on the $\mathrm{X}$-ray films were scanned, digitized, and the signal intensities were numerically converted. The signal intensities of the spots on the membranes obtained from two separate experiments were analyzed using the GEArray analyzer program (SuperArray Bioscience Corp.) after subtraction of the background levels of pUC18 DNA. The average of glyceraldehyde-3-phosphate dehydrogenase (GAPDH) was used as positive control to compare the membranes.

synthesis and secretion in a gonadotrope cell line L $\beta \mathrm{T} 2$. BMP-15 selectively stimulates FSH biosynthesis and secretion by rat primary pituitary cells without affecting LH secretion or GnRHR transcription (Otsuka \& Shimasaki 2002). Lee et al. (2007) reported an interesting observation that BMP-2 and activin A synergistically and independently stimulate FSH $\beta$ transcription in L $\beta$ T2 cells. In their study, BMP-2 enhanced FSH $\beta$ transcription using cells transfected with mouse $1.9 \mathrm{~kb}$ FSH $\beta$ reporter construct (Lee et al. 2007). However, BMP-2 effect on FSH $\beta$ transcriptional activation was negligible compared with activin A actions in our present study using ovine $4.7 \mathrm{~kb}$ FSH $\beta$ promoter. This difference could be due to the assay sensitivity or the possible actions of 5'-distal FSH $\beta$ regulatory region on modulating BMPresponsive FSH $\beta$ transcription.

Alexander et al. (1995) study have shown that a binding protein for activin/BMP, follistatin is expressed in more than half of nonfunctioning adenomas as well as in normal human pituitary tissues. Interestingly, follistatin expression was not detected in other functioning adenomas, including prolactinomas, growth hormone-, and ACTH-producing adenomas in the same study (Alexander et al. 1995). Penabad et al. (1996) also showed that follistatin protein is detected in nonadenomatous gonadotropes but barely in gonadotropinomas, in which follistatin immunoreactivity is co-localized with FSH $\beta$ subunit in the cytoplasm.

Since FSH-producing pituitary adenomas express the activin- $\beta \mathrm{B}$ subunit, impairment of activin neutralization due to reduced follistatin may result in increased cell mitosis and FSH hypersecretion in gonadotropinomas. In this regard, we previously showed the critical difference between FSHproducing adenoma and nonfunctioning adenoma with respect to the level of follistatin mRNA (Takeda et al. 2003). Namely, in nonfunctioning adenomas, the expression of follistatin is abundant and thereby the activation of activin/ BMP signaling is insufficient, resulting in less production of FSH despite the existence of activins and BMPs. On the contrary, in gonadotropinomas, the effect of follistatin is negligible and thereby activins can bind their receptor and transduce the signaling effectively to stimulate FSH synthesis and secretion (Takeda et al. 2003).

Regarding the pituitary BMP system, BMP-2 and BMP-4 play a key role for the initial development of the anterior pituitary (Scully \& Rosenfeld 2002). BMP-4 is required during the first stage of pituitary organogenesis for the proliferation of the Rathke's pouch, which gives rise to Pit-1 lineage cells including lactotrope cells. Moreover, overexpression of noggin or a dominant-negative ALK-3 in the anterior pituitary leads to the arrest of the development of Pit-1-expressing lineage (Scully \& Rosenfeld 2002). During the second stage of pituitary organogenesis, an inhibition of BMP-2, a ventro-dorsal gradient, by an FGF-8, a dorso-ventral gradient, leads to differentiation of corticotrope cells (Dasen \& Rosenfeld 2001). Overexpression of FGF-8 in the developmental pituitary results in defect of Pit-1 lineage cells with enhanced differentiation of corticotrope cells, implying that inhibition of the BMP signaling is necessary for corticotrope development (Kioussi et al. 1999).

BMP-4 not only governs pituitary organogenesis, but also plays a key role in the pathogenesis of differentiated pituitary lineages. It is reported that BMP-4 is overexpressed in the lactotrope adenoma derived from dopamine type-2 receptor (D2R) null mouse as well as human prolactinomas (Paez-Pereda et al. 2003). Of particular interest, a binding protein for BMPs, noggin expression is conversely downregulated in the prolactinoma from the $\mathrm{D} 2 \mathrm{R}$ null mouse (Paez-Pereda et al. 2003), suggesting a new concept that BMP-4 promotes cell proliferation in lactotoropes in conjunction with Smad-estrogen receptor interaction under 


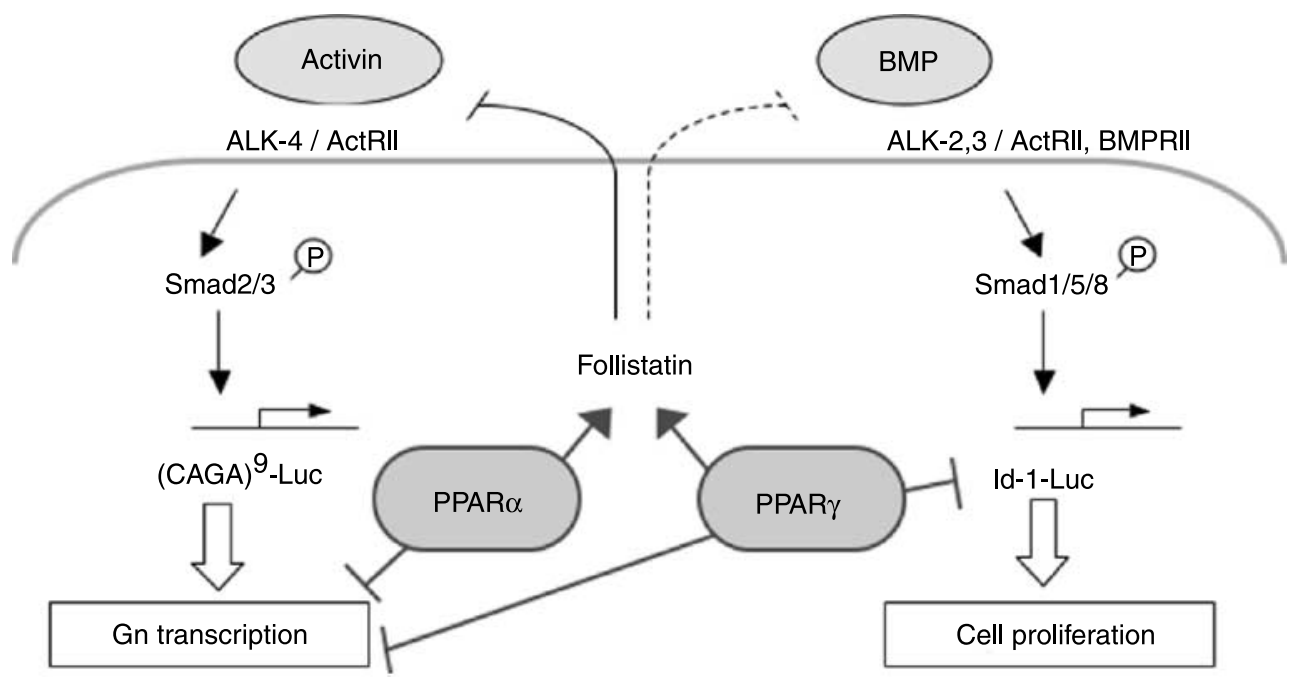

Figure 9 A possible mechanism by which PPAR regulates gonadotropin transcription and cell proliferation in gonadotrope cells. L $\beta T 2$ cells express BMP type I and type II receptors, and transcription factor Smads. Neither PPAR $\alpha$ nor PPAR $\gamma$ affects activin signaling, whereas both PPAR agonists suppress transcriptional activities of gonadotropins (Gn) directly. Activation of PPAR $\gamma$, but not PPAR $\alpha$, specifically suppresses BMP signaling of L $\beta$ T2 cells, leading to inhibition of cell mitosis. PPARs enhance follistatin mRNA expression that sequesters biological actions of activin.

the influence of its binding protein. BMP-4 also inhibits ACTH secretion and cell proliferation of corticotropinoma cells (Giacomini et al. 2006). In addition, anti-proliferative effect of retinoic acid on corticotropinoma seems to be mediated by the BMP-4 action. Thus, BMP-4 promotes pituitary prolactinoma through a Smad-estrogen receptor crosstalk (Paez-Pereda et al. 2003), while BMP-4 inhibits corticotrope pathogenesis, i.e. Cushing's disease (Giacomini et al. 2006).

As seen in the imbalanced expression of BMP-4 and noggin by lactotrope adenomas (Paez-Pereda et al. 2003), the intrapituitary regulation of activin/BMPs by follistatin may be involved in the functional transition between nonfunctioning adenomas and FSH-producing adenomas in vivo. Based on our earlier data, the expression levels of BMP-6 and BMP-7 were lowered while that of activin- $\beta B$ subunit was increased in FSH-producing adenomas (Takeda et al. 2003), implying involvement of the pituitary activin/BMP system in development of gonadotropinomas. Interestingly, PPAR $\gamma$ activation increased expression of BMP-6 and BMP-7 mRNAs while reduced that of activin- $\beta B$ mRNA in L $\beta$ T2 cells in the present results, suggesting the reminiscent pattern shown in nonfunctioning adenomas rather than FSHproducing adenomas.

It seems likely that PPAR agonists not only directly suppress gonadotropin transcription and BMP signaling, but also inhibit effects of endogenous activins on gonadotropin transcription through upregulating follistatin expression. Therefore, one may consider that PPAR $\alpha$ and PPAR $\gamma$ might be involved in differentiation of gonadotropinoma from nonfunctioning adenomas by modulating follistatin transcription in the pituitary adenomas. In contrast to the changes in follistatin expression, mRNA levels of FLRG, which has been reported to regulate biological actions of activins $\mathrm{A}, \mathrm{B}$ and $\mathrm{AB}$, and BMP-2 (Tsuchida 2004), were not altered by PPAR activation in L $\beta T 2$ cells. Arai et al. (2003) reported that FLRG plays important roles in the regulation of reproductive events, especially in the placenta and decidua during the latter half of pregnancy. In their study, FLRG mRNA was weakly detected in the rat pituitary, as shown in L $\beta \mathrm{T} 2$ cells. The finding that FLRG, but not follistatin, expression was increased by activin also provides the possibility of differential regulation of transcription between FLRG and follistatin in pituitary gonadotrope as shown in other tissues such as placenta and skin (Wankell et al. 2001, Wang et al. 2003). Roles of FLRG in gonadotrope cells need to be further elucidated in the future study.

Collectively, the present study demonstrates PPAR regulation of gonadotropin transcription and tumorigenesis of pituitary gonadotrope cells partly through regulating the endogenous BMP/activin/follistatin system (Fig. 9). PPAR activation in gonadotropes may play a key role in determining capability of gonadotropins production in the pituitary, which may be linked to differentiation between nonfunctioning and FSH-producing adenomas.

\section{Acknowledgements}

We thank Dr Pamela L Mellon for L $\beta$ T2 cells, Drs William L Miller and Pamela L Mellon for the oFSH $\beta$-Luc, LH $\beta$-Luc, and GnRHR-Luc plasmids. We thank Dr R Kelly Moore for 
helpful discussion and critical reading of the manuscript. We also thank Drs Tetsuro Watabe and Kohei Miyazono for providing Id-1-Luc plasmid. This work was supported in part by Grants-in-Aid for Scientific Research, Yamaguchi Endocrine Research Association, Takeda Science Foundation, The Tokyo Biochemical Research Foundation, Sakakibara Memorial Research Grant, The Ichiro Kanehara Foundation, and Kato Memorial Bioscience Foundation. The authors declare that there is no conflict of interest that would prejudice the impartiality of this scientific work.

\section{References}

Alexander JM, Swearingen B, Tindall GT \& Klibanski A 1995 Human pituitary adenomas express endogenous inhibin subunit and follistatin messenger ribonucleic acids. Journal of Clinical Endocrinology and Metabolism 80 147-152.

Arai KY, Tsuchida K, Uehara K, Taya K \& Sugino H 2003 Characterization of rat follistatin-related gene: effects of estrous cycle stage and pregnancy on its messenger RNA expression in rat reproductive tissues. Biology of Reproduction 68 199-206.

Auwerx J 1999 PPAR $\gamma$, the ultimate thrifty gene. Diabetologia 42 1033-1049.

Dasen JS \& Rosenfeld MG 2001 Signaling and transcriptional mechanisms in pituitary development. Annual Review of Neuroscience 24 327-355.

Desvergne B \& Wahli W 1999 Peroxisome proliferator-activated receptors: nuclear control of metabolism. Endocrine Reviews 20 649-688.

Emery MN, Leontiou C, Bonner SE, Merulli C, Nanzer AM, Musat M, Galloway M, Powell M, Nikookam K, Korbonits M et al. 2006 PPAR- $\gamma$ expression in pituitary tumours and the functional activity of the glitazones: evidence that any anti-proliferative effect of the glitazones is independent of the PPAR-gamma receptor. Clinical Endocrinology 65 389-395.

Giacomini D, Paez-Pereda M, Theodoropoulou M, Labeur M, Refojo D, Gerez J, Chervin A, Berner S, Losa M, Buchfelder M et al. 2006 Bone morphogenetic protein-4 inhibits corticotroph tumor cells: involvement in the retinoic acid inhibitory action. Endocrinology 147 247-256.

Gurnell M 2005 Peroxisome proliferator-activated receptor gamma and the regulation of adipocyte function: lessons from human genetic studies. Best Practice and Research. Clinical Endocrinology and Metabolism 19 501-523.

Heaney AP 2003 Novel pituitary ligands: peroxisome proliferator activating receptor-gamma. Pituitary 6 153-159.

Heaney AP, Fernando M, Yong WH \& Melmed S 2002 Functional PPARgamma receptor is a novel therapeutic target for ACTH-secreting pituitary adenomas. Nature Medicine 8 1281-1287.

Heaney AP, Fernando M \& Melmed S 2003 PPAR-gamma receptor ligands: novel therapy for pituitary adenomas. Journal of Clinical Investigation 111 1381-1388.

Huang H-J, Wu JC, Su P, Zhirnov O \& Miller WL 2001 A novel role for bone morphogenetic proteins in the synthesis of follicle-stimulating hormone. Endocrinology 142 2275-2283.

Inagaki K, Otsuka F, Suzuki J, Kano Y, Takeda M, Miyoshi T, Otani H, Mimura Y, Ogura T \& Makino H 2006 Involvement of bone morphogenetic protein- 6 in differential regulation of aldosterone production by angiotensin II and potassium in human adrenocortical cells. Endocrinology 147 2681-2689.

Kano Y, Otsuka F, Takeda M, Suzuki J, Inagaki K, Miyoshi T, Miyamoto M, Otani H, Ogura T \& Makino H 2005 Regulatory roles of bone morphogenetic proteins and glucocorticoids in catecholamine production by rat pheochromocytoma cells. Endocrinology 146 5332-5340.

Kioussi C, Carriere C \& Rosenfeld MG 1999 A model for the development of the hypothalamic-pituitary axis: transcribing the hypophysis. Mechanisms of Development 81 23-35
Lee KB, Khivansara V, Santos MM, Lamba P, Yuen T, Sealfon SC \& Bernard DJ 2007 Bone morphogenetic protein 2 and activin A synergistically stimulate follicle-stimulating hormone beta subunit transcription. Journal of Molecular Endocrinology 38 315-330.

Lefebvre AM, Chen I, Desreumaux P, Najib J, Fruchart JC, Geboes K, Briggs M, Heyman R \& Auwerx J 1998 Activation of the peroxisome proliferatoractivated receptor gamma promotes the development of colon tumors in C57BL/6J-APCMin/ + mice. Nature Medicine 4 1053-1057.

Lehmann JM, Moore LB, Smith-Oliver TA, Wilkison WO, Willson TM \& Kliewer SA 1995 An antidiabetic thiazolidinedione is a high affinity ligand for peroxisome proliferator-activated receptor gamma (PPAR gamma). Journal of Biological Chemistry 270 12953-12956.

Miyoshi T, Otsuka F, Suzuki J, Takeda M, Inagaki K, Kano Y, Otani H, Mimura Y, Ogura T \& Makino H 2006 Mutual regulation of folliclestimulating hormone signaling and bone morphogenetic protein system in human granulosa cells. Biology of Reproduction 74 1073-1082.

Miyoshi T, Otsuka F, Inagaki K, Otani H, Takeda M, Suzuki J, GotoJ, Ogura T \& Makino H 2007 Differential regulation of steroidogenesis by bone morphogenetic proteins in granulosa cells: involvement of extracellularly regulated kinase signaling and oocyte actions in follicle-stimulating hormoneinduced estrogen production. Endocrinology 148 337-345.

Otsuka F \& Shimasaki S 2002 A novel function of bone morphogenetic protein-15 in the pituitary: selective synthesis and secretion of FSH by gonadotropes. Endocrinology 143 4938-4941.

Otsuka F, Yao Z, Lee TH, Yamamoto S, Erickson GF \& Shimasaki S 2000 Bone morphogenetic protein-15: identification of target cells and biological functions. Journal of Biological Chemistry 275 39523-39528.

Otsuka F, Moore RK \& Shimasaki S 2001 Biological function and cellular mechanism of bone morphogenetic protein-6 in the ovary. Journal of Biological Chemistry 276 32889-32895.

Paez-Pereda M, Giacomini D, Refojo D, Nagashima AC, Hopfner U, Grubler Y, Chervin A, Goldberg V, Goya R, Hentges ST et al. 2003 Involvement of bone morphogenetic protein 4 (BMP-4) in pituitary prolactinoma pathogenesis through a Smad/estrogen receptor crosstalk. PNAS 100 1034-1039.

Palakurthi SS, Aktas H, Grubissich LM, Mortensen RM \& Halperin JA 2001 Anticancer effects of thiazolidinediones are independent of peroxisome proliferator-activated receptor gamma and mediated by inhibition of translation initiation. Cancer Research 61 6213-6218.

Penabad JL, Bashey HM, Asa SL, Haddad G, Davis KD, Herbst AB, Gennarelli TA, Kaiser UB, Chin WW \& Snyder PJ 1996 Decreased follistatin gene expression in gonadotroph adenomas. Journal of Clinical Endocrinology and Metabolism 81 3397-3403.

Pernasetti F, Vasilyev VV, Rosenberg SB, Bailey JS, Huang HJ, Miller WL \& Mellon PL 2001 Cell-specific transcriptional regulation of follicle-stimulating hormone-beta by activin and gonadotropin-releasing hormone in the L $\beta$ T2 pituitary gonadotrope cell model. Endocrinology 142 2284-2295.

Scully KM \& Rosenfeld MG 2002 Pituitary development: regulatory codes in mammalian organogenesis. Science 295 2231-2235.

Suzuki J, Otsuka F, Inagaki K, Takeda M, Ogura T \& Makino H 2004 Novel action of activin and bone morphogenetic protein in regulating aldosterone production by human adrenocortical cells. Endocrinology 145 639-649.

Suzuki J, Otsuka F, Takeda M, Inagaki K, Miyoshi T, Mimura Y, Ogura T, Doihara H \& Makino H 2005 Functional roles of the bone morphogenetic protein system in thyrotropin signaling in porcine thyroid cells. Biochemical and Biophysical Research Communications 327 1124-1130.

Takeda M, Otsuka F, Suzuki J, Kishida M, Ogura T, Tamiya T \& Makino H 2003 Involvement of activin/BMP system in development of human pituitary gonadotropinomas and nonfunctioning adenomas. Biochemical and Biophysical Research Communications 306 812-818.

Takeda M, Otsuka F, Nakamura K, Inagaki K, Suzuki J, Miura D, Fujio H, Matsubara H, Date H, Ohe T et al. 2004 Characterization of the bone morphogenetic protein (BMP) system in human pulmonary arterial smooth muscle cells isolated from a sporadic case of primary pulmonary hypertension: roles of BMP type IB receptor (activin receptor-like kinase-6) in the mitotic action. Endocrinology 145 4344-4354. 
Tsuchida K 2004 Activins, myostatin and related TGF-beta family members as novel therapeutic targets for endocrine, metabolic and immune disorders. Current Drug Targets. Immune, Endocrine and Metabolic Disorders 4 157-166.

Wang HQ, Takebayashi K, Tsuchida K, Nishimura M \& Noda Y 2003 Follistatinrelated gene (FLRG) expression in human endometrium: sex steroid hormones regulate the expression of FLRG in cultured human endometrial stromal cells. Journal of Clinical Endocrinology and Metabolism 88 4432-4439.

Wankell M, Kaesler S, Zhang YQ, Florence C, Werner S \& Duan R 2001 The activin binding proteins follistatin and follistatin-related protein are

differentially regulated in vitro and during cutaneous wound repair. Journal of Endocrinology 171 385-395.
Willson TM, Brown PJ, Sternbach DD \& Henke BR 2000 The PPARs: from orphan receptors to drug discovery. Journal of Medicinal Chemistry 43 $527-550$.

Received in final form 8 April 2007

Accepted 18 April 2007

Made available online as an Accepted Preprint 19 April 2007 